\title{
Anti-oxidant and Anti-bacterial Activities of Mouthwash Prepared with Acacia Flower, Songji, and Topan Solar Salt
}

\author{
Suk-Hee Youn, Jung-Soon Han ${ }^{*}$, Ae-Jung Kim* \\ Department of Nutrition Therapy, Graduate School of Alternative Medicine, Kyonggi University, Seoul, Korea
}

\author{
*Corresponding authors: Ae-Jung Kim, \\ Department of Nutrition Therapy, Graduate \\ School of Alternative Medicine, Kyonggi \\ University, 24 Kyonggidae-ro, 9-gil, \\ Seodaemun-gu, Seoul 03746, Korea \\ Tel.: +82 23905044 \\ Fax: +82 23905078 \\ Email: aj5249@naver.com \\ Jung-Soon Han, Department of Nutrition \\ Therapy, Graduate School of Alternative \\ Medicine, Kyonggi University, 24 Kyonggidae- \\ ro, 9-gil, Seodaemun-gu, Seoul 03746, Korea \\ Tel.: +82 23905044 \\ Fax: +82 23905078 \\ Email: yohwa0620@gmail.com \\ Ae-Jung Kim and Jung-Soon Han equally \\ contributed to this work.
}

Received January 17, 2017

Revised April 8, 2017

Accepted April 17, 2017

Published June 30, 2017

\begin{abstract}
Purpose: This study investigated the anti-oxidant and anti-bacterial activities of mouthwash prepared using freeze dried acacia flower hot water extracts (FDAFWEx), including songji and topan solar salt, and created a natural mouthwash. Methods: The anti-oxidant activity of acacia flowers was measured by the radical scavenging activities of 1,1-diphenyl-2-picrylhydrazyl (DPPH) and 2,2'-azino-bis (3-ethylbenzothiazoline-6-sulfonic acid) diammonium salt (ABTS) using freeze drying, roasting, and hot air drying. The anti-oxidant activity was estimated using the radical scavenging activity of the DPPH in the mouthwash. The anti-bacterial activity was evaluated using the paper disk diffusion method. Results: The greatest anti-oxidant activity of acacia flowers was observed in the FDAFWEx. The anti-oxidant activity of mouthwash was increased by adding FDAFWEx in a dose-dependent manner. The anti-bacterial activity was increased by including the FDAFWEx content. Conclusion: FDAFWEx was determined to have anti-oxidant and anti-bacterial activities, and it is anticipated that mouthwash containing FDAFWEx could be a natural mouthwash.
\end{abstract}

Keywords: Anti-oxidant activity, Anti-bacterial activity, Mouthwash, Acacia flower, Songji

\section{Introduction}

최근 우리나라는 설탕과 설탕이 함유된 탄수화물 가공식품의 소비 가 지속적으로 늘어남에 따라 구강질환 예방을 위한 구강위생관리의 필요성이 증가하였다(Ciancio, 1992; Kim et al., 2007). 구강질환은 치은연하(subgingival)에 존재하는 치태세균에 의한 감염성질환으로 치아상실을 초래하는 주된 원인으로 보고되었다(Slots, 1979).

치아관련 질환을 일으키는 균 중 Streptococcus mutans $(S$. mutans)는 치아면에 부착하여 증식 및 산 생성 과정을 거치면서 치
아우식을 유발하는 균이다(Hamada et al., 1984). S. mutans는 균체 외 또는 균체 표층에서 치아우식의 유발효소인 glucosyltransferase (GTase)라는 효소를 분비하는데, GTase는 음식물 중 수크로스 (sucrose)를 분해하여 치아면에 불용성 글루칸(glucan)을 형성하 게 된다(Hanada \& Takehara, 1987). 글루칸이 구강 내 다른 미생 물들과 치아면에 부착하여 치면세균막(dental plaque)을 생성하면 (Hamada \& Slade, 1980), 치아우식 유발균과 혐기성 세균이 증식 하면서 생성된 산에 의해 치아의 칼슘염 상실로 법랑질이 약해져 치 아우식증이 유발된다(Gibbons \& Houte, 1975; Takahashi, 2005). 
Staphylococcus aureus (S, aureus)는 건강한 사람의 비강이나 인 후의 점막, 피부에 있는 정상 세균총으로 기회 감염을 통해 국소 및 전신감염을 유발하는 그람양성구균으로, 화농성 감염의 $80 \%$ 이 상을 차지하는 감염성 질환의 주요 원인균으로 피부의 가벼운 감 염부터 창상 감염, 균혈증, 농가진, 독성쇼크증후군(toxic shock syndrome), 기관지 폐렴, 장독소에 의한 식중독, 패혈증, 급성심 내막염, 심근염, 심막염, 수막염 등의 중요한 원인균이다(Chung \& Lee, 1993). 이러한 세균들의 비율이 증가하면서 치주염으로 진행된 다(Assev et al., 1989).

구강질환을 예방하고 치주질환의 발생을 억제하기 위해서는 칫 솔질이나 치실, 항생제나 구강세정제 등의 사용이 있는데 그 중 구 강세정제는 구강 내 세균 활성을 억제하고 소염작용 등을 통해 구 강질환을 예방하고 치료하는데 도움을 줄 수 있다(Corner et al., 1988). 구강세정제는 구강환경 내에서 원인 균주 및 치주염이나 구 취 유발세균에 대해 선택적인 항균력을 지니면서 주위 조직에 독 성이 없어야 한다(Cho et al., 2014). 그러나 대부분의 시판 중인 구 강세정제에는 항균작용과 충치균 생성 억제 효능이 있는 클로르헥 시딘(chlorhexidine), 트리클로산(triclosan), 세틸피리디늄클로라 이드(cetylpyridinium chloride)의 화학합성 제재를 함유하고 있으 며 일부 제품에는 항생제를 첨가한 제품들도 시판되고 있어 장기 간 사용 시 항생제 내성 부작용을 일으킬 수 있는 문제점이 지적되 고 있다(Kim et al., 2011). 뿐만 아니라 클로르헥시딘은 항균 효과 는 높으나 장기 사용 시 치아 및 혀의 변색, 미각 이상, 점막 자극 과 민증을 유발시키고 소비자의 기호를 떨어뜨리는 점이 지적되고 있 어(Song et al., 2001), 화학성분의 부작용을 줄이고 장기간 사용해 도 안전한 천연물을 원료로 하는 구강세정제에 대한 요구가 증가하 고 있다(Cho et al., 2014).

아까시꽃에는 항산화 효과가 우수한 아스코르브산(ascorbic acid) 및 탄닌산(tannic acid)이 많이 함유되어 있으며 그 외 유리당이나 무기질의 함량 또한 비교적 높은 것으로 보고되었다(Kwon et al., 1995). 송지(Songji, pine resin turpentine)는 소나무과(Pinaceae) 소나무속(Pinus) 식물의 줄기의 상처에서 자연히 생긴 황갈색 덩 어리로 피넨(pinene), 카렌(careen), 테르피넨(terpinene) 등의 정 유성분이 10\%, 피멜린산(pimelic acid), 레보피마르산(levopimaric acid) 등의 수지성분이 $90 \%$ 함유되어 있다(Namba, 1980). 송지에 관한 연구로는 송지의 항염증 및 진통작용(Choi et al., 2006), 송지 와 식염의 구강세균 증식 억제 효과(Cho et al., 2014), 비듬균 증식 억제 효과(Suk, 2004) 등이 알려져 있다. 예로부터 천연 구강세정 제 재료로 사용되어 온 소금은 항염작용, 살균 및 방부 효과가 있는 것으로 알려져 있다(Mandel, 1988). 특히 천일염은 살균, 상처치 유, 피부보호, 항염증의 효능이 있어 구강위생 또는 염증완화 등의 목적으로 다양하게 사용되어 왔으며(Kim et al., 2015), 천일염과 토판염으로 제조한 김치 메탄올 추출물이 HT-29 암세포의 성장을 억제하는 효과가 있다는 보고도 있다(Yoon \& Chang, 2011).
이에 본 연구에서는 천연 소재 가운데 아까시꽃의 건조방법에 따 른 항산화 효과를 관찰하여 가장 우수한 항산화성을 나타낸 건조방 법을 확인한 후 아까시꽃, 송지와 토판염을 혼합한 천연 구강세정제 를 제조하고 항산화 및 항균 효과를 관찰하여 천연물을 이용한 구강 질환 예방을 위한 구강세정제 개발을 하고자 하였다.

\section{Methods}

\section{1. 연구 재료}

본 실험에 사용한 아까시(Robinia pseudoacacia L.)꽃은 충청북 도 옥천 지역에서 채취한 것을 구입하여 사용하였으며, 송지는 경 동시장(Korea)에서, 토판염은 서대문구에 위치한 농협(Korea)에서 구매하여 사용하였다.

\section{2. 건조방법에 따른 아까시꽃의 항산화 활성 측정}

\section{1) 시료 제조}

항산화 활성 측정용 시료 제조는 아까시꽃을 동결건조, 덖음건조 (로스팅), 열풍건조의 세 가지 방식으로 전 처리하였다.

\section{2) 열수추출물 제조}

전 처리방법(동결건조, 덖음건조, 열풍건조)을 달리한 아까시꽃 시료들의 무게 대비 각각 20 배 부피의 증류수를 첨가한 후 환류냉각 관을 부착한 $80^{\circ} \mathrm{C}$ 의 heating mantle (HM250C; Sercrim Labtech, Korea)에서 $3 \mathrm{~h}$ 동안 추출시켜 여과(Whatman ${ }^{\circledR}$ qualitative filter paper No.2; GE Healthcare Life Sciences, USA)하여 얻었다. 이렇 게 2,3 차 추출액을 얻어 모두 혼합한 후 rotary vacuum evaporator (HS-2005S-N; Hahnshin S\&T, Korea)로 용매를 증발시켜 $50 \mathrm{~mL}$ 까지 농축하여 동결건조 시킨 후 분석용 시료로 사용하였다.

\section{3) Total polyphenol 함량}

전 처리방법을 달리하여 열수추출한 아까시꽃 시료들의 총 폴 리페놀 함량은 Folin \& Denis (1912) 방법으로 측정하였다. 추출 물 $1 \mathrm{~mL}$ 을 취하여 $2 \%(\mathrm{w} / \mathrm{v})$ sodium carbonate (Sigma-Aldrich, USA) 용액 $1 \mathrm{~mL}$ 를 가해 $3 \mathrm{~min}$ 방치한 후, $50 \%$ Folin-Ciocalteu 시약(Sigma-Aldrich) $0.2 \mathrm{~mL}$ 를 가하여 $750 \mathrm{~nm}$ 에서 흡광도 (microplate reader, BN 02514; Molecular Devices, USA)를 측정 하였다. 총 페놀 함량은 tannic acid (Sigma-Aldrich)를 이용하여 작성한 표준곡선을 바탕으로 환산하여 나타내었다.

\section{4) Total flavonoid 함량}

전 처리방법을 달리한 아까시꽃 열수추출물 시료의 총 플라보노 이드 함량은 Davis (1947) 방법을 변형하여 측정하였다. 즉, 추출물 $400 \mu \mathrm{L}$ 에 diethylene glycol (Sigma-Aldrich) $4 \mathrm{~mL}$ 를 첨가하고 다 
시 $1 \mathrm{~N}$ sodium hydroxide (Sigma-Aldrich) $40 \mu \mathrm{L}$ 를 첨가한 후 $37^{\circ} \mathrm{C}$ 에서 $1 \mathrm{~h}$ 반응 후 $420 \mathrm{~nm}$ 에서 흡광도를 측정하였다. 총 플라보노이 드 함량은 rutin (Sigma-Aldrich)을 이용하여 작성한 표준곡선을 바 탕으로 환산하여 나타내었다.

\section{5) DPPH 라디칼 소거능}

전 처리방법을 달리하여 열수추출한 아까시꽃 시료의 $\mathrm{DPPH}$ 라 디칼 소거능은 Blois (1958)의 방법을 변형하여 다음과 같이 실시 하였다. 추출물 $0.1 \mathrm{~mL}$ 에 $1.5 \times 10^{-4} \mathrm{M} \mathrm{DPPH}$ (Sigma-Aldrich) 용 액 $0.1 \mathrm{~mL}$ 을 가하여 실온, 암실에서 $30 \mathrm{~min}$ 방치한 후 $517 \mathrm{~nm}$ 에 서 흡광도를 측정하였다. 추출물의 처리 농도에 따른 $\mathrm{DPPH}$ 라디 칼을 $50 \%$ 억제하는데 요구되는 농도인 half maximal inhibitory concentration $\left(\mathrm{IC}_{50}\right)$ 값으로 비교하였으며, 모든 실험은 3회 반복하 여 평균값으로 계산하였다. 대조용 시료로는 vitamin C (SigmaAldrich)를 사용하였다.

\section{6) ABTS 라디칼 소거능}

전 처리방법을 달리한 아까시꽃 열수추출물 시료의 ABTS 라 디칼 소거능은 Fellegrini et al. (1999)의 방법으로 측정하였다. ABTS (Sigma-Aldrich) $7.4 \mathrm{mM}$ 과 potassium persulfate (SigmaAldrich) $2.6 \mathrm{mM}$ 을 하루 동안 암소에 방치하여 $\mathrm{ABTS}$ 양이온을 형 성시킨 후 $735 \mathrm{~nm}$ 에서 흡광도 값이 1.4-1.5가 되도록 증류수로 희 석하였다. 희석된 $\mathrm{ABTS}$ 용액 $1 \mathrm{~mL}$ 에 추출물 시료 $50 \mu \mathrm{L}$ 를 가하여 흡광도의 변화를 $60 \mathrm{~min}$ 후에 측정하였다. 추출물의 처리 농도에 따른 $\mathrm{ABTS}$ 라디칼을 $50 \%$ 억제하는데 요구되는 농도 $\left(\mathrm{IC}_{50}\right)$ 로 비교하 였으며, 모든 실험은 3 회 반복하여 평균값으로 계산하였다. 대조용 시료로는 vitamin $\mathrm{C}$ 를 사용하였다.

\section{3. 구강세정제의 항산화 및 항균 활성 측정}

1) 구강세정제 제조

아까시꽃, 송지 및 토판염을 이용한 구강세정제는 Table 1에 제시 된 바와 같은 비율로 혼합하여 제조하였다. 아까시꽃은 시료 무게 (70 g) 대비 20배 $(1,400 \mathrm{~mL})$ 의 증류수를 첨가한 후 환류냉각관을 부 착한 $80^{\circ} \mathrm{C}$ 의 heating mantle에서 $3 \mathrm{~h}$ 추출시켜 여과하여 얻은 후 rotatory vacuum evaporator로 용매를 증발시켜 첨가한 증류수량
의 25\% (350 mL)까지 농축하여 동결건조 시킨 후 사용하였다. 송 지는 곱게 마쇄한 후 시료 무게 대비 5 배의 $99.9 \%$ 에탄올(SigmaAldrich)을 가해서 용해시킨 다음 동일한 양의 증류수를 가해 얻은 현탁액을 솜으로 여과하여 지방의 응집물과 침전물을 제거한 후 에 탄올과 증류수를 증발시킨 후 시료 무게 대비 1 배의 $50 \%$ 에탄올로 시료를 재 용해한 후 사용하였다. 토판염은 제조한 송지 용액에 용 해시킨 후 사용하였다.

\section{2) 항산화 활성}

동결건조한 아까시꽃 열수추출물(FDAFWEx)과 송지와 토판 염 혼합물(solution of songji and topan solar salt mixture (3:1), STM)을 이용하여 제조한 구강세정제는 각각 무게 대비 10배의 부 피의 $70 \%$ 에탄올을 가하여 실온에서 $24 \mathrm{~h}$ 추출시켜 여과하여 얻었 다. 추출액을 rotatory vacuum evaporator로 용매를 증발시켜 50 $\mathrm{mL}$ 까지 농축하여 동결건조 시킨 후 total polyphenol 함량, total flavonoid 함량, $\mathrm{DPPH}$ 라디칼 소거능을 측정하였다.

\section{3) 항균 활성}

(1) 균주 및 배양

항균력 시험에는 $S$. mutans (KCTC 5365)와 $S$, aureus (KCTC 1621)를 생물자원센터(Korean Collection for Type Cultures; $\mathrm{KCTC}$, Korea)에서 분양 받아 사용하였다. 균주별 특성에 따라 배 양조건을 달리하여 $S$. mutans는 brain heart infusion agar (26 $\mathrm{g} / 500 \mathrm{~mL}$; Becton, Dickinson and Company, USA)를 넣은 한 천배지에 $37^{\circ} \mathrm{C}$ 에서 혐기성 조건으로 배양하였다. S. aureus는 nutrient broth (4 g/500 mL; Becton, Dickinson and Company)에 agar (Sigma-Aldrich)를 넣은 한천배지에서 호기성 조건에서 $37^{\circ} \mathrm{C}$ 로 배양을 하였다.

\section{(2) 항균 활성 측정}

S. mutans와 $S$, aureus에 대한 항균 활성은 확산한천법(paper disk diffusion method)으로 측정하였다. FDAFWEx와 STM 비율 을 달리하여 제조한 구강세정제 및 대조군을 $30 \mu \mathrm{L}$ 씩 직경 $8 \mathrm{~mm}$, 두께 $1.5 \mathrm{~mm}$ 의 종이 디스크(filter paper; Advantec MFS, USA)에 흡수시킨 후, 용매를 완전히 증발시킨다. 균주의 배양은 혐기성 조

Table 1. Mouthwash formula

\begin{tabular}{lccc}
\hline Group & FDAFWEx $(\mathrm{mL})$ & Water $(\mathrm{mL})$ & $\mathrm{STM}(\mathrm{mL})$ \\
Control & 0 & 90 & 10 \\
AMw30 & 30 & 60 & 10 \\
AMw60 & 60 & 30 & 10 \\
AMw90 & 90 & 0 & 10 \\
\hline
\end{tabular}

FDAFWEx, freeze dried acacia flower hot water extracts; STM, solution of songji and topan solar salt mixture (3:1); AMw30, sample was prepared with FDAFWEx $30 \mathrm{~mL}$, water $60 \mathrm{~mL}$, and STM $10 \mathrm{~mL}$; AMw60, sample was prepared with FDAFWEx $60 \mathrm{~mL}$, water $30 \mathrm{~mL}$, and STM 10 $\mathrm{mL}$; AMw90, sample was prepared with FDAFWEx $90 \mathrm{~mL}$ and STM $10 \mathrm{~mL}$ without water. 
건 및 호기성 조건으로 $37^{\circ} \mathrm{C}$ 에서 $24 \mathrm{~h}$ 배양하였다. 항균 활성의 측 정은 종이 디스크 주변에 형성된 원형의 생육억제환 크기를 측정하 고 비교하는 방법으로 수행하였고, 모든 시험은 독립적으로 3 회 반복 하였다.

\section{4. 통계 처리}

모든 자료는 statistical package for the social sciences (SPSS) statistics 21 (BMM, USA)을 이용하여 평균과 표준편차를 구하고, 시료간의 유의성은 analysis of variance (ANOVA)를 실시한 후, Duncan's multiple range test로 각 시료의 평균차이에 대한 사후 검 정을 유의수준 $5 \%$ 에서 실시하였다.

\section{Results and Discussion}

\section{1. 아까시꽃의 항산화 활성}

1) Total polyphenol 함량과 total flavonoid 함량

건조방법을 달리한 아까시꽃 열수추출물 시료들의 총 폴리페놀 함량과 총 플라보노이드 함량은 Table 2 에 제시된 바와 같다.

총 폴리페놀 함량은 동결건조 아까시꽃 열수추출물(FDAFWEx) 이 $37.88 \mathrm{mg}$ tannic acid equivalent (TAE)/g, 덖음건조 아까시꽃 열수추출물(roasted acacia flower hot water extracts, RAFWEx)이 이 $32.62 \mathrm{mg} \mathrm{TAE} / \mathrm{g}$, 열풍건조 아까시꽃 열수추출물(hot air dried acacia flower hot water extracts, ADAFWEx)이 $30.56 \mathrm{mg}$ TAE/ $\mathrm{g}$ 순으로 나타나, FDAFWEx의 총 폴리페놀 함량이 가장 높았으며,
이는 아까시꽃 에탄올추출물의 총 폴리페놀 함량이 $39.65 \pm 2.30$ $\mathrm{mg}$ 을 나타내었다는 Lee et al. (2012)의 결과와 비슷한 경향을 나타 내었다.

총 플라보노이드 함량 역시 총 폴리페놀과 마찬가지로 $\mathrm{FDAFWEx}$ 이 $17.21 \mathrm{mg}$ rutin equivalent (RE)/g, RAFWEx이 $11.56 \mathrm{mg} \mathrm{RE} / \mathrm{g}$, $\mathrm{ADAFWEx}$ 이 $9.30 \mathrm{mg} \mathrm{RE} / \mathrm{g}$ 순으로 나타나, FDAFWEx의 총 플라 보노이드 함량이 가장 높았다. 폴리페놀은 페놀산(phenolic acid)류 와 플라보노이드(flavonoid)류, 쿠마린(coumarin)류, 탄닌(tannin) 류로 분리되며 그 중 대부분이 플라보노이드류이다. 이들은 활성 자 유라디칼에 수소원자를 제공하여 안정한 비 라디칼(non-radical)을 만들어 항산화 효과를 나타낸다. 또한 미생물의 세포막 구성물질인 펩티도글리칸(peptidoglycan)의 합성을 방해하여 세포막 이상을 유 발하며, 단백질과 핵의 합성을 해하여 항균 효과를 나타낸다. 그러 므로 본 연구결과에서 $\mathrm{FDAFWEx}$ 에는 폴리페놀이 많이 함유되어 있어 항산화 효과가 우수한 것으로 생각된다.

\section{2) DPPH 라디칼 소거능과 ABTS 라디칼 소거능}

건조방법을 달리한 아까시꽃 열수추출물 시료들의 $\mathrm{DPPH}$ 라디칼 소거능과 ABTS 라디칼 소거능은 Table 3에 제시된 바와 같다.

$\mathrm{DPPH}$ 라디칼 소거능의 $\mathrm{IC}_{50}$ 값은 $\mathrm{FDAFWEx}$ 이 $123.73 \mu \mathrm{g} / \mathrm{mL}$, RAFWEx이 $224.64 \mu \mathrm{g} / \mathrm{mL}, \mathrm{ADAFWEx}$ 이 $351.96 \mu \mathrm{g} / \mathrm{mL}$ 순으로 나 타나 FDAFWEx의 DPPH 라디칼 소거 활성이 가장 좋게 나타났다.

$\mathrm{ABTS}$ 라디칼 소거능의 $\mathrm{IC}_{50}$ 값 역시 $\mathrm{DPPH}$ 라디칼 소거능의 $\mathrm{IC}_{50}$ 값과 마찬가지로 FDAFWEx $203.27 \mu \mathrm{g} / \mathrm{mL}, \mathrm{RAFWEx} 303.81 \mu \mathrm{g} /$ $\mathrm{mL}, \mathrm{ADAFWEx} 448.74 \mu \mathrm{g} / \mathrm{mL}$ 순으로 나타나 FDAFWEx의 소거

Table 2. Content of total polyphenol and total flavonoid according to the drying method

\begin{tabular}{lcc}
\hline Group & Total polyphenol content $(\mathrm{mg}$ TAE/g) & Total flavonoid content (mg RE/g) \\
FDAFWEx & $37.88 \pm 1.75^{1, a, 2)}$ & $17.21 \pm 0.15^{\mathrm{a}}$ \\
RAFWEx & $32.62 \pm 1.59^{\mathrm{b}}$ & $11.56 \pm 0.21^{\mathrm{b}}$ \\
ADAFWEx & $30.56 \pm 0.56^{\mathrm{b}}$ & $9.30 \pm 0.14^{\mathrm{c}}$ \\
\hline
\end{tabular}

TAE, tannic acid equivalent; RE, rutin equivalent; FDAFWEx, freeze dried acacia flower hot water extracts; RAFWEx, roasted acacia flower hot water extracts; ADAFWEx, hot air dried acacia flower hot water extracts.

${ }^{1)}$ Mean \pm standard deviation $(n=3)$.

${ }^{2)}$ Means with different letters in the same column are significantly different at $p<0.05$ according to Duncan's multiple range test.

Table 3. Radical scavenging activities of DPPH and ABTS according to the drying method

\begin{tabular}{lcc}
\hline Group & $I_{50}$ value of DPPH radical $(\mu \mathrm{g} / \mathrm{mL})$ & $\mathrm{IC}_{50}$ value of ABTS radical $(\mu \mathrm{g} / \mathrm{mL})$ \\
FDAFWEx & $123.73 \pm 5.61^{1),(, 2)}$ & $203.27 \pm 6.37^{\circ}$ \\
RAFWEx & $224.64 \pm 20.33^{\mathrm{b}}$ & $303.81 \pm 22.73^{\mathrm{b}}$ \\
ADAFWEx & $351.96 \pm 8.83^{\mathrm{a}}$ & $448.74 \pm 9.90^{\mathrm{a}}$ \\
Vitamin C & $18.26 \pm 1.53^{\mathrm{d}}$ & $20.07 \pm 1.10^{\mathrm{d}}$ \\
\hline
\end{tabular}

DPPH, 1,1-diphenyl-2-picrylhydrazyl; ABTS, 2,2'-azino-bis (3-ethylbenzothiazoline-6-sulfonic acid) diammonium salt; $I C_{50}$, half maximal inhibitory concentration; FDAFWEx, freeze dried acacia flower hot water extracts; RAFWEx, roasted acacia flower hot water extracts; ADAFWEx, hot air dried acacia flower hot water extracts; Vitamin C, positive control.

${ }^{1)}$ Mean \pm standard deviation $(n=3)$.

${ }^{2}$ Means with different letters in the same column are significantly different at $p<0.05$ according to Duncan's multiple range test. 
활성이 가장 좋게 나타났다. 이는 구강세정제로 사용하고자 연구했 던 황칠나무 추출물의 $\mathrm{DPPH}$ 라디칼 소거능과 $\mathrm{ABTS}$ 라디칼 소거능 이 vitamin C의 항산화 활성과 유사하며 butylated hydroxytoluene (BHT)보다도 $40 \%$ 이상이나 더 높은 활성을 가지고 있다는 Park et al. (2013)의 결과만큼 우수하지는 않았으나 아까시꽃 건조방법에 따라서는 $\mathrm{FDAFWEx}$ 의 항산화 활성이 높게 나타났다. 또한 아까시 잎보다는 꽃 추출물의 유리기 제거 효과가 높았으며, 플라보노이드 도 많이 함유되어 있기 때문이라고 추측된다는 Choi et al. (2006) 결과와 비슷한 경향을 나타내었다.

\section{2. 구강세정제의 항산화 활성과 항균 활성}

1) $\mathrm{DPPH}$ 라디칼 소거능

가장 항산화 활성이 우수한 FDAFWEx, 송지 및 토판염을 이용하 여 제조한 구강세정제의 $\mathrm{DPPH}$ 라디칼 소거능은 Table 4 에 제시된 바와 같다.

$\mathrm{DPPH}$ 라디칼 소거능은 FDAFWEx가 $40.65 \%$, 송지 현탁액
에 토판염을 용해시킨 $\mathrm{STM}$ 이 $55.23 \%, \mathrm{FDAFWEx}$ 를 첨가하지 않은 $\mathrm{AMw} 0$ 은 $6.93 \%, \mathrm{FDAFWEx}$ 를 $30 \mathrm{~mL}$ 첨가 시(AMw30)에 는 $28.13 \%, \mathrm{FDAFWEx}$ 를 $60 \mathrm{~mL}$ 첨가 시(AMw60)에는 $42.86 \%$, $\mathrm{FDAFWEx}$ 를 $90 \mathrm{~mL}$ 첨가 시(AMw90)에는 $50.72 \%$ 로 나타나 $\mathrm{FDAFWEx}$ 의 첨가량이 증가할수록 $\mathrm{DPPH}$ 라디칼 소거 활성이 유의 하게 높아졌다 $(p<0.05)$. 이는 천연물인 황칠나무 추출물의 항산화 효과가 합성항산화제 BHT보다 우수하다고 나온 결과(Park et al., 2013)로 판단할 때 긍정적인 결과로 사료된다.

\section{2) 항균 활성}

동결건조 아까시꽃 열수추출물 첨가량에 따른 $S$. mutans와 $S$. aureus에 대한 항균 활성의 결과는 Table 5 에 제시된 바와 같다.

S. mutans에 대한 항균 활성은 FDAFWEx가 $25.00 \mathrm{~mm}, \mathrm{STM}$ 이 $13.85 \mathrm{~mm}, \mathrm{AMw0}$ 은 $8.23 \mathrm{~mm}, \mathrm{AMw} 30$ 은 $12.65 \mathrm{~mm}, \mathrm{AMw60}$ 은 $18.05 \mathrm{~mm}, \mathrm{AMw} 90$ 은 $23.10 \mathrm{~mm}$, positive control인 A사의 구강세 정제는 $30.15 \mathrm{~mm}$ 의 생육억제환을 나타내었다.

\section{Table 4. Radical scavenging activity of DPPH in mouthwash product prepared with different levels of FDAFWEx}

\begin{tabular}{lc}
\hline Group & Radical scavenging activity of DPPH (\%) \\
FDAFWEx & $40.65 \pm 2.27^{1, \mathrm{~b}, 2)}$ \\
STM & $55.23 \pm 4.38^{\mathrm{a}}$ \\
AMw0 & $6.93 \pm 0.95^{\mathrm{e}}$ \\
AMw30 & $28.13 \pm 1.28^{\mathrm{c}}$ \\
AMw60 & $42.86 \pm 2.65^{\mathrm{b}, \mathrm{c}}$ \\
AMw90 & $50.72 \pm 2.84^{\mathrm{b}}$ \\
\hline
\end{tabular}

DPPH, 1,1-diphenyl-2-picrylhydrazyl; FDAFWEx, freeze dried acacia flower hot water extracts; STM, solution of songji and topan solar salt mixture (3:1); AMw0, sample was prepared with water $90 \mathrm{~mL}$ and STM $10 \mathrm{~mL}$ without FDAFWEx; AMw30, sample was prepared with FDAFWEx 30 $\mathrm{mL}$, water $60 \mathrm{~mL}$, and STM $10 \mathrm{~mL}$; AMw60, sample was prepared with FDAFWEx $60 \mathrm{~mL}$, water $30 \mathrm{~mL}$, and STM $10 \mathrm{~mL}$; AMw90, sample was prepared with FDAFWEX $90 \mathrm{~mL}$ and STM $10 \mathrm{~mL}$ without water.

${ }^{1)}$ Mean \pm standard deviation $(n=3)$.

${ }^{2)}$ Means with different letters are significantly different at $p<0.05$ according to Duncan's multiple range test.

Table 5. Anti-bacterial activities of mouthwash product prepared with different levels of FDAFWEx on S. mutans and S. aureus

\begin{tabular}{lcc}
\hline \multirow{2}{*}{ Group } & \multicolumn{2}{c}{ Clear zone diameter $(\mathrm{mm})^{1)}$} \\
\cline { 2 - 3 } FDAFWEx & S. mutans & S. aureus \\
STM & $25.00 \pm 0.14^{2, \mathrm{~b}, 3)}$ & $20.75 \pm 0.10^{\mathrm{b}}$ \\
AMw0 & $13.85 \pm 0.49^{f}$ & $11.20 \pm 0.20^{\mathrm{f}}$ \\
AMw30 & $8.23 \pm 0.43^{\mathrm{i}}$ & $8.21 \pm 0.26^{\mathrm{i}}$ \\
AMw60 & $12.65 \pm 0.28^{\mathrm{g}}$ & $10.30 \pm 0.10^{\mathrm{g}}$ \\
AMw90 & $18.05 \pm 0.21^{\mathrm{e}}$ & $15.00 \pm 0.20^{\mathrm{e}}$ \\
\hline Positive control & $23.10 \pm 0.57^{\mathrm{c}}$ & $19.95 \pm 0.15^{\mathrm{c}}$ \\
\hline
\end{tabular}

S. mutans, Streptococcus mutans; S. aureus, Staphylococcus aureus; FDAFWEx, freeze dried acacia flower hot water extracts; STM, solution of songji and topan solar salt mixture (3:1); AMw0, sample was prepared with water $90 \mathrm{~mL}$ and STM $10 \mathrm{~mL}$ without FDAFWEx; AMw30, sample was prepared with FDAFWEX $30 \mathrm{~mL}$, water $60 \mathrm{~mL}$, and STM $10 \mathrm{~mL}$; AMw60, sample was prepared with FDAFWEx $60 \mathrm{~mL}$, water $30 \mathrm{~mL}$, and STM $10 \mathrm{~mL}$; AMw90, sample was prepared with FDAFWEx $90 \mathrm{~mL}$ and STM $10 \mathrm{~mL}$ without water; Positive control, A company mouthwash.

${ }^{1)}$ Clear zone diameter includes the diameter of filter paper $(8 \mathrm{~mm})$.

${ }^{2)}$ Mean \pm standard deviation $(n=3)$.

${ }^{3}$ Means with different letters in the same column are significantly different at $p<0.05$ according to Duncan's multiple range test. 
S. aureus에 대한 항균 활성은 FDAFWEx가 $20.75 \mathrm{~mm}, \mathrm{STM}$ 이 $11.20 \mathrm{~mm}, \mathrm{AMw0}$ 은 $8.21 \mathrm{~mm}, \mathrm{AMw} 30$ 은 $10.30 \mathrm{~mm}, \mathrm{AMw} 60$ 은 $15.00 \mathrm{~mm}, \mathrm{AMw} 90$ 은 $19.95 \mathrm{~mm}$, positive control은 $34.75 \mathrm{~mm}$ 의 생육억제환을 나타내었다. FDAFWEx의 첨가량이 증가할수록 $S$. mutans와 $S$. aureus 균의 성장억제 면적이 증가하여 아까시꽃 열 수추출물의 첨가량이 증가할수록 항균력이 높아졌다. 즉, 평판배지 확산법을 이용하여 치아관련 질환 원인균의 일종인 $S . m u t a n S$ 와 $S$. aureus에 대한 항균 활성을 확인한 결과, 아까시꽃, 송지 및 토판염 을 이용한 구강세정제는 치아관련 질환 예방을 위한 $\mathrm{A}$ 사의 구강세 정제와 비교했을 때, 구강질환의 원인균에 대한 항균 활성이 벤제토 늄클로라이드(benzethonium chloride)이나 클로르헥시딘과 같은 화 학물질이 첨가되지 않았음에도 우수한 항균 활성 수준을 나타냈다. 이상의 결과로 본 연구에서 아까시꽃 추출물을 첨가한 구강세정제 가 $S$. mutans와 $S$. aureus에 대해 항균 활성을 나타낸 것은 천연물 을 이용한 구강세정제 개발의 기초자료로 활용될 수 있는 가능성을 제시하는 긍정적 결과로 사료되는 바이다.

\section{Conclusion}

본 연구에서는 아까시꽃의 건조방법에 따른 항산화 활성을 측정 한 결과 동결건조 방법이 가장 항산화 활성이 우수하였다. 이에 아 까시꽃을 동결건조하여 열수추출한 $\mathrm{FDAFWEx}$ 을 송지 및 토판염과 혼합하여 제조한 천연 구강세정제의 항산화 활성과 항균 활성을 측 정하였다. 그 결과, $\mathrm{FDAFWEx}$ 첨가량이 증가할수록 $\mathrm{DPPH}$ 라디칼 소거능이 유의하게 높아졌음을 확인하였다. S. mutans와 $S$, aureus 균에 대한 항균 활성도 $\mathrm{FDAFWEx}$ 첨가량이 증가할수록 높게 나타 났다. 이상의 결과를 통해, FDAFWEx, 송지 및 토판염을 이용하여 제조한 구강세정제는 구강위생관리를 위한 천연 구강세정제로서의 가능성이 있을 것으로 사료되며 향후 천연 구강세정제에 대한 연구 가 더 진행되기를 기대하는 바이다.

This work is part of Suk-Hee Youn's M.S. thesis at Kyonggi University, Seoul, Korea.

\section{References}

Assev S, Scheie AA, Rolla G. Potential of xylitol, mannitol, and sorbose to inhibit metabolism in Streptococcus sobrinus OMZ 176. Journal of Dental Research, 68: 1729-1731, 1989.

Blois MS. Antioxidant determinations by the use of a stable free radical. Nature, 181: 1199-1200, 1958.
Cho BJ, Hong JY, Kim M, Song YO. Development of mouthwash products with solid fermented oriental medicinal herb. Journal of the Korean Society of Food Science and Nutrition, 43: 1380-1387, 2014.

Choi IH, Choi TH, Park Y, Lee OK, Kwon YH, Kang HY, Park IK, Choi DH, Shin SC, Lee HJ. Studies on biological activity of wood extractives (X VII): components and antioxidant activity of Alnus firma. Journal of the Korean Wood Science and Technology, 34: 95-100, 2006.

Chung KS, Lee HJ. Studies of nasal carriage and antimicrobial susceptibility test of Staphylococcus aureus in college students and general hospital personnel in Incheon city. Journal of Environmental Health Sciences, 19: 71-76, 1993.

Ciancio SG. Agents for the management of plaque and gingivitis. Journal of Dental Research, 71: 1450-1454, 1992.

Corner AM, Dolan MM, Yankell SL, Malamud D. C31G, a new agent for oral use with potent antimicrobial and antiadherence properties. Antimicrobial Agents and Chemotherapy, 32: 350-353, 1988.

Davis WB. Determination of flavanones in citrus fruits. Analytical Chemistry, 19: 476-478, 1947.

Fellegrini N, Ke R, Yang M, Rice-Evans C. Screening of dietary carotenoids and carotenoid-rich fruit extracts for antioxidant activities applying 2,2'-azinobis (3-ethylenebenzothiazoline-6-sulfonic acid) radical cation decolorization assay. Methods in Enzymology, 299: 379389, 1999.

Folin O, Denis W. On phosphotungstic-phosphomolybdic compounds as color reagents. The Journal of Biological Chemistry, 12: 239-243, 1912.

Gibbons RJ, Houte JV. Bacterial adherence in oral microbial ecology. Annual Review of Microbiology, 29: 19-44, 1975.

Hamada S, Koga T, Ooshima T. Virulence factors of Streptococcus mutans and dental caries prevention. Journal of Dental Research, 63: 407-411, 1984.

Hamada S, Slade HD. Biology, immunology, and cariogenicity of Streptococcus mutans. Microbiological Reviews, 44: 331-384, 1980.

Hanada N, Takehara T. (1 $\rightarrow 3)-\alpha-D$-glucan synthase from Streptococcus mutans AHT (serotype g) does not synthesise glucan without primer. Carbohydrate Research, 168: 120-124, 1987. 
Kim DH, Yoon YS, Joo KB, Lee KJ. The evaluation of efficacy on oral cavity cleaner (dental cleaner). Korean Journal of Waters, 2: 1-8, 2011.

Kim JH, Ji CS, Jung BM, Kim BO, Yu SJ. Effect of mouthwash containing sun-dried salt on gingivitis and halitosis. Oral Biology Research, 39: 120-126, 2015.

Kim S, Jang HJ, Yoo YG, Chu YS, Park YH, Park JW. The effect of mouthrinse products containing deep sea water. Journal of the Korean Association of Oral and Maxillofacial Surgeons, 33: 601-608, 2007.

Kwon JH, Byun MW, Kim YH. Chemical composition of acacia flower (Robinia pseudo-acacia). Korean Journal of Food Science and Technology, 27: 789-793, 1995.

Lee JY, Ko SH, Mun SJ, You JH, Kim SW. Analysis on the antioxidant activity and total phenolics in Robinia pseudoacacia L., exotic species. The Journal of Korean Institute of Forest Recreation, 16: 101-105, 2012.

Mandel ID. Chemotherapeutic agents for controlling plaque and gingivitis. Journal of Clinical Periodontology, 15: 488498, 1988.

Namba T. The encyclopedia of Wakan-Yaku with color pictures. Hoikusha Publishing, Osaka, p191, 1980.
Park SA, Park J, Park Cl, Jie YJ, Hwang YC, Kim YH, Jeon SH, Lee HM, Ha JH, Kim KJ, et al. Cellular antioxidant activity and whitening effects of Dendropanax morbifera leaf extracts. Microbiology and Biotechnology Letters, 41: 407-415, 2013.

Slots J. Subgingival microflora and periodontal disease. Journal of Clinical Periodontology, 6: 351-382, 1979.

Song WS, Son SH, Chung HJ. A clinical trial of dextranasecontaining mouthwash on the inhibition of plaque formation and gingivitis. Journal of Dental Science, 13: 343-360, 2001.

Suk KD. Inhibitory effect of resina pini on growth of Malassezia furfur Bailon. Journal of Korean Society for Hygienic Sciences, 10: 227-231, 2004.

Takahashi N. Microbial ecosystem in the oral cavity: metabolic diversity in an ecological niche and its relationship with oral diseases. International Congress Series, 1284: 103112, 2005

Yoon HH, Chang HC. Growth inhibitory effect of kimchi prepared with four year-old solar salt and topan solar salt on cancer cells. Journal of the Korean Society of Food Science and Nutrition, 40: 935-941, 2011. 


\section{국문초록}

\section{아까시꽃, 송지 및 토판염을 이용한 구강세정제의 항산화 및 항균 활성}

윤석희, 한정순

경기대학교 대체의학대학원 식품치료전공, 서울, 한국

목적: 본 연구는 동결건조 아까시꽃 열수추출물을 송지 및 토판염과 혼합하여 제조한 구강세정제의 항산화 활성과 항균 활성을 측 정하여 천연 구강세정제로서의 가능성을 탐색하고자 수행되었다. 방법: 아까시꽃을 동결건조, 덖음건조, 열풍건조 방법으로 항산 화 활성을 1,1-diphenyl-2-picrylhydrazyl (DPPH) 라디칼 소거능과 2,2-azino-bis (3-ethylbenzothiazoline-6-sulfonic acid) diammonium salt (ABTS) 라디칼 소거능으로 측정하였다. 구강세정제의 항산화 활성은 DPPH 라디칼 소거능으로 측정하였다. 항 균 활성은 확산한천법에 의해 평가하였다. 결과: 아까시꽃은 동결건조하였을 때 가장 항산화 활성이 우수하였다. 동결건조 아까시 꽃 열수추출물의 첨가 함유량이 증가할수록 항산화 활성이 증가하였다. 항균 활성도 동결건조 아까시꽃 열수추출물의 첨가량이 증 가할수록 높게 나타났다. 결론: 이상의 결과 동결건조 아까시꽃 열수추출물, 송지 및 토판염을 이용하여 제조한 구강세정제는 항산 화 및 항균 효과를 나타내어 구강위생관리를 위한 천연 구강세정제로서의 가능성을 기대할 수 있을 것으로 사료된다.

핵심어: 항산화 활성, 항균 활성, 구강세정제, 아까시꽃, 송지

\section{참고문헌}

권중호, 변명우, 김영회. 아카시아(Robinia pseudo-acacia) 꽃의 화학성분 조성. 한국식품과학회지, 27: 789-793, 1995. 김동희, 윤양숙, 주경복, 이규재. 구강청결제(덴탈크리어)의 효능 평가. 한국물학회지, 2: 1-8, 2011. 김선아, 장해진, 유영근, 추용식, 박양호, 박준우. 해양심층수를 이용한 구강청정제의 효과. 대한구강악안면외과학회지, $33:$ 601-608, 2007.

박수아, 박준, 박찬일, 지영종, 황윤찬, 김용현, 전소하, 이혜미, 하지훈, 김경진, 등. 황칠나무 잎 추출물의 세포 항산화 활성

과 미백활성 측정. 한국미생물 · 생명공학회지, 41: 407-415, 2013.

석귀덕. 송지(松脂)의 비듬균(Malassezia furfur Bailon) 증식 억제 효과. 한국위생과학회지, 10: 227-231, 2004.

송우성, 손성희, 정현주. Dextranase 함유 구강 세정액의 치태 제거 및 치은염 예방 효과에 관한 임상적 연구. 구강과학, $13:$

343-360, 2001.

윤해훈, 장해춘. 토판염 및 4년 숙성 천일염으로 제조한 김치의 암세포 성장 억제 효과. 한국식품영양과학회지, 40: 935-941, 2011.

이준영, 고성현, 문성주, 유주한, 김상욱. 외래종 아까시나무의 항산화 효과와 총 페놀류 함량 분석. 한국산림휴양학회지, $16:$ 101-105, 2012.

정경석, 이희주. 인천시내 일부 종합병원 종사자와 대학생의 비강내 Staphylococcus aureus의 보균상태 및 항균제에 대한 감 수성. 한국환경보건학회지, 19: 71-76, 1993.

조병제, 홍준영, 김미정, 송영옥. 고체발효 한약재 추출물을 함유한 구강세척제 개발. 한국식품영양과학회지, 43: 13801387, 2014. 


\section{中文摘要}

\section{刺槐、松脂和土版盐漱口剂的抗氧化及抗菌活性}

尹錫姬，韓正順*，金愛貞 ${ }^{*}$

京畿大学代替医疗大学院食品治疗学科, 首尔, 韩国

目的：利用冷冻干燥的刺槐花热水提取物、松脂和土版盐混合制备漱口剂并测定抗氧化活性和抗菌活性，探索其作 为天然漱口剂的适用可行性。方法：对刺槐花分别采用冷冻干燥、焙烧、热风干燥等预处理, 并测定1,1-diphenyl-2picrylhydrazyl (DPPH)自由基消除能力和2,2'-azino-bis (3-ethylbenzothiazoline-6-sulfonic acid) diammonium salt (ABTS) 自由基消除能力来评价抗氧化活性。对漱口剂的抗氧化活性通过DPPH自由基消除能力来测定。利用纸片扩善法 来评价抗菌活性。结果: 刺槐花在冷冻干燥时, 其抗氧化活性最优秀。冷冻干燥的刺槐花热水提取物的含量增加, 其抗 氧化活性以及抗菌活性也随之增加。结论: 通过以上结果得出, 利用冷冻干燥的刺槐花热水提取物、松脂和土版盐混合 制备的漱口剂具有抗氧化及抗菌效果，因此作为口腔卫生管理天然漱口剂充分具有可行性。

关键词: 抗氧化活性，抗菌活性，漱口剂，刺槐花，松脂 